Kiyonori Miura $\cdot$ Hideaki Masuzaki $\cdot$ Tadayuki Ishimaru

Norio Niikawa • Yoshihiro Jinno

\title{
A Hhal/BstUl polymorphism in a novel gene at human chromosome 11p15.5
}

Received: July 24, 1998 / Accepted: July 29, 1998

\begin{abstract}
We found a HhaI/Bst UI polymorphism in the $3^{\prime}$ untranslated region of a novel gene which was localized to $11 \mathrm{p} 15.5$. This region is one of prominent imprinting domains and contains multiple imprinted genes, such as $H 19$, $I G F 2, K V L Q T 1$, and $p 57^{K I P 2}$, which suggests that regional factors might contribute to the imprinting.

This polymorphism will be useful in the allelic analysis of expression and methylation of the novel gene.
\end{abstract}

Key words Imprinting $\cdot 11 \mathrm{p} 15.5 \cdot$ polymorphism $\cdot$ PCRRFLP

\section{Introduction}

Imprinted genes are often found to cluster in particular chromosomal regions and form imprinted domains (Zemel et al. 1992), although the significance of their clustering in the imprinting mechanism remains to be revealed. In the mouse and the human, there are at least two major imprinted domains. One is the human chromosome $11 \mathrm{p} 15.5$ region, where the imprinted genes H19, IGF2, KVLQT1, $p 57^{K I P 2}$, and others are located (Zhang and Tycko 1992, Jinno et al. 1995, Giannoukakis et al. 1993, Lee et al. 1997, Matsuoka et al. 1996). We isolated a novel gene (PEN11B) which was localized to $11 \mathrm{p} 15.5$, using a repetitive sequence consisting of pentanucleotide elements found in the human $H 19$ enhancer region (GenBank Accession No. AF020089).

In order to analyze the allelic expression of the gene, we found a HhaI/Bst UI restriction fragment length polymorphism (RFLP) in its 3' untranslated region (UTR).

K. Miura $\cdot$ N. Niikawa $\cdot$ Y. Jinno $(\square)$

Department of Human Genetics, Nagasaki University School of

Medicine, 1-12-4 Sakamoto, Nagasaki, 852-8523 Japan

Tel. +81-95-849-7176; Fax +81-95-849-7121

e-mail: siriusyj@net.nagasaki-u.ac.jp

K. Miura $\cdot$ H. Masuzaki $\cdot$ T. Ishimaru

Department of Obstetrics and Gynecology, Nagasaki University

School of Medicine, Nagasaki, Japan
Polymerase chain reaction (PCR) primers

The PCR primers used were:

BSTA: 5'-GTCACCTGACCCCTCAGCAA-3' and BSTb: 5'-CACCAGCTCTGTCCTCAGAG-3'.

PCR conditions

For the HhaI/Bst UI RFLP, PCR was carried out in a total volume of $50 \mu \mathrm{l}$, containing $0.5 \mu \mathrm{g}$ genomic DNA, $0.5 \mu \mathrm{M}$ of each primer, $0.2 \mathrm{mM}$ in each dNTP, $5 \mu 110 \times$ PCR-buffer, $10 \mu \mathrm{l}$ of $50 \%$ glycerol, and $1.5 \mathrm{UTaq}$ polymerase (Perkin Elmer, Norwalk, CT, USA) for 28 cycles with an automated thermal cycler (DNA Thermal Cycler PJ2000; Perkin Elmer) as follows: denaturation at $94^{\circ} \mathrm{C}$ for 3 min for the first cycle and for $90 \mathrm{~s}$ for further cycles, annealing at $59^{\circ} \mathrm{C}$ for $70 \mathrm{~s}$, and extension at $72^{\circ} \mathrm{C}$ for $90 \mathrm{~s}$. The PCR product was phenol/chloroform-extracted, ethanol-precipitated, and digested with $H h a \mathrm{I} / B s t \mathrm{UI}$. The restriction digests were separated in a $6 \%$ polyacrylamide gel.

\section{Polymorphism and allele frequency}

HhaI (Bst UI) digestion generated a 201 (263)-bp fragment in the A1 allele without the $H h a \mathrm{I}(B s t \mathrm{UI})$ and a 167 (208)-bp fragment in the A2 allele (Fig. 1). The estimated A1/A2 allele frequencies in 64 normal Japanese are shown in Table 1.

Table 1 Allele frequencies of HhaI restriction fragment length polymorphism in 64 normal Japanese individuals

\begin{tabular}{lllll}
\hline Enzyme & Allele & $\begin{array}{l}\text { Fragment } \\
\text { size (bp) }\end{array}$ & Frequency & Heterozygosity \\
\hline Hha & A1 & 201 & 0.625 & 0.469 \\
& A2 & 167 & 0.375 & \\
\hline
\end{tabular}


(bp)

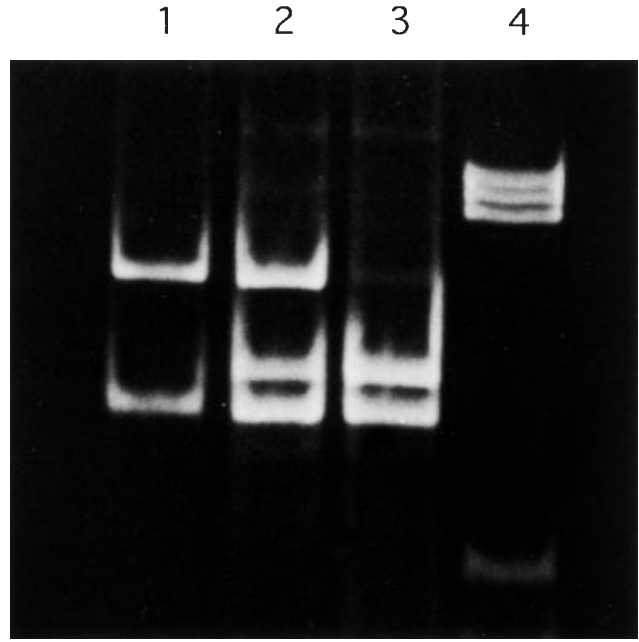

Fig. 1 Hha I restriction fragment length polymorphism. Lanes 1-3 indicate a homozygote for A1, heterozygote for A1/A2, and a homozygote for A2, respectively. Lane 4 is the size marker, AluI-cut pUC19 DNA

Mendelian inheritance. Codominant segregation was observed in three two-generation families.

Chromosomal localization. The gene was assigned to 11 p15.5 by fluorescence in situ hybridization.
Acknowledgments The present study was partly supported by a Grant-in-Aid for Scientific Research from the Ministry of Education, Science, and Culture of Japan, and by a grant for Research on Human Genome and Gene Therapy from the Ministry of Health and Welfare of Japan.

\section{References}

Giannoukakis N, Deal C, Paquette J, Goodyer CG, Polychronakos C (1993) Parental genomic imprinting of the human IGF2 gene. Nature Genet 4: 98-101

Jinno Y, Ikeda Y, Yun K, Maw M, Masuzaki H, Fukuda H, Inuzuka K, Fujishita A, Ohtani Y, Okimoto T, Ishimaru T, Niikawa N (1995) Establishment of functional imprinting of the $H 19$ gene in human developing placentae. Nature Genet 10: 318-324

Lee MP, Hu RJ, Johnson LA, Feinberg AP (1997) Human KVLQT1 gene shows tissue-specific imprinting and encompasses BeckwithWiedemann syndrome chromosomal rearrangements. Nature Genet 15: $181-185$

Matsuoka S, Thompson JS, Edwards MC, Barletta JM, Grundy P, Kalikin LM, Harper JW, Elledge SJ, Feinberg AP (1996) Imprinting of the gene encoding a human cyclin dependent kinase inhibitor, $p 57^{K I P 2}$, on chromosome 11p15. Proc Natl Acad Sci USA 93: 30263030

Zemel S, Bartolomei MS, Tilghman SM (1992) Physical linkage of two mammalian imprinted genes, $H 19$ and insulin-like growth factor 2 . Nature Genet 2: 61-65

Zhang Y, Tycko B (1992) Monoallelic expression of the human H19 gene. Nature Genet 1: 40-44 